\title{
Connection Between Strategic Alliance Value AND The Controlling Potential of THE Management of All the Alliance Members
}

\author{
Plazibat,I.; Peronja,I. \& Veza,I.
}

Abstract: The aim of the paper is to investigate the dependence of relationship between controllers and a strategic alliance management on compatibility management of alliance partners. Developmental tendencies of controlling task and its functions have resulted in support of management in order to reduce the risk in making managerial decisions. However, every company (i.e. its management) is not equally successful in implementing and exploitation of concept of controlling. Making a strategic alliance successful requires the same amount of will and knowledge of all member companies. We will try to prove a positive correlation of mental awareness and education level of individual management members in an alliance and the success of strategic alliances management. The research was conducted in the retail market whose consolidation is becoming its distinct feature, which increases the relevance of strategic alliances as objects of the research. Research results indicate that the cooperation between controllers and managers in the alliance is greater if the alliance members are compatible in their human resources and operations. This relation, however, is not a criterion for finding a partner for an alliance that is compatible in management.

Key words: strategic alliances, retail, controlling, management, strategic management
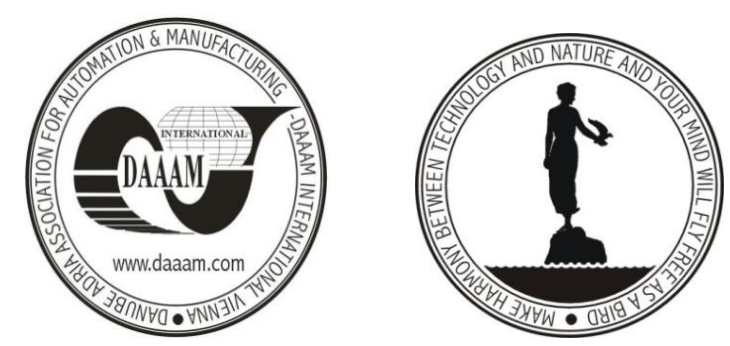

Authors' data: Plazibat, I[vana]*, Peronja,I[van]*, Veza,I[vica]**, *University of Split, Department for Professional studies, Livanjska 5/III, 21000 Split, Croatia, **University of Split, Faculty of electrical engineering, mechanical engineering and naval architecture, Ruđera Boškovića 31, 21000 Split, Croatia, E-mail: iplazibat@oss.unist.hr, iperonja@ net.hr, iveza@ fesb.hr

This Publication has to be referred as: Plazibat, I[vana]; Peronja, I[van] \& Veza, I[vica] (2014). Connection Between Strategic Alliance Value and the Controlling Potential of the Management of All the Alliance Members, Chapter 18 in DAAAM International Scientific Book 2014, pp.207-220, B. Katalinic (Ed), Published by DAAAM International, ISBN 978-3-901509-98-8, ISSN 1726-9687, Vienna, Austria DOI: $10.2507 /$ daaam.scibook.2014.18 


\section{Introduction}

Croatia's retail market is still considered to be in transition. The latest market indicators suggest grouping of retailers in strategic alliances and the possibility to achieve long-term advantage over competitors by implementing controlling. Considering these, we tried to point out the possibility to achieve long-term advantage over competitors through value-oriented management; and likewise through management which in itself implies the concept of controlling of strategic alliances, as well as the value of a strategic alliance by implementing controlling function. To make it possible, we set up the thesis of the necessary compatibility management of member companies in an alliance, i.e. the thesis that the relation between management and controllers in the alliance depends on the compatibility management of the member companies. The research was conducted in retail market of the Republic of Croatia. It was an excellent testing ground because of its specificities and final business internationalization of its subjects that make Croatian retail market an excellent foundation for the formation of strategic alliances and confirm the need to implement controlling function as a support to strategic alliances management. A sample of this research is defined by the number of strategic alliances in the retail trade at the time of conducting research, the management number of member companies in a particular alliance and the organizational structure of the individual members. The research was conducted from October 2010. till October 2011.

\section{Theoretical overview of the elements of strategic alliances controlling}

Controlling is a function and a subsystem of management which contributes to efficiency and effectiveness in the work of management. (Osmanagić, 2004)

Several authors dealt with the subject of controlling. It should be noted that a number of authors analyse controlling in cooperative relationship which is only one form of strategic alliances.

The success of achieving the set goals is a proof of a properly established company's strategy, i.e. its vision and its mission. However, all companies are not successful in establishing their long-term growth and development strategy and in achieving a competitive advantage in any market and / or industry.

Companies try to confirm their strength by achieving profit levels (i.e. a guarantee contribution which is in accounting referred to as a contribution margin), but also by growth in market share that can be achieved either by the individual forces or in cooperation with companies in the same or different levels of distribution channels. Size of the guarantee contribution is central for the controller in measuring the realization of the goals. It refers to profit that remains to cover fixed operating costs. After covering fixed costs we get the size of a full guarantee contributions or net profit by Luković, T., Lebefromm, U (2009) Given that in the interest of each company is not to lose its own identity, more and more companies tend to merge together in some kind of strategic alliances. Specifically, strategic alliances are 
focused on achieving synergistic financial performance, which can be expressed as follows: in which:

$$
\text { NPV }(A+B+C+n)>N P V(A)+N P V(B)+N P V(C)+N P V(n),
$$

NPV $(A+B+C+n)$ - synergetic net present value of the strategic alliance;

NPV (A) - net present value of an individual company A;

NPV (B) - net present value of an individual company B;

NPV (C) - net present value of an individual company C; (2010)

NPV (n) - net present value of any individual company $n$ by Zaboj, M.

Achieving the group's synergistic effect is measured by achieving a defined aim of every company and that is their profit. Every company which enters into a strategic alliance, or rather the company's management, firstly wants to confirm the success of the selected strategy which is looked into with the primary purpose of increasing its own profit. Then the company's management looks into the success of strategic alliance and the alliance management in completing the objectives of the alliance, which represent compromise of individual aims (motives for entering an alliance) of alliance members. In achieving success, controlling and implemented concept of controlling get crucial importance. Managerial function that is focused on controlling indicates the management oriented towards problems, objectives, profit, bottlenecks and future strategic alliances. Considering the success of individual companies and the concept of controlling and if the strategic alliance management wants to increase the probability of success and the increasing impact of the desired synergetic level, it should introduce support in the form of controlling, or employ a controller (best evidence of that are numerous companies in Germany and established colleges that study controlling). Consequently, strategic alliance management should decide whether it will act as a controller and then we talk about control-oriented strategic alliances management or it will single out a person as a controller to support decision making, and then we talk about strategic alliance controller. However, it should be noted that the success of control-oriented strategic alliances management or of a strategic alliance controller depends primarily on how the partner companies themselves are control oriented, which means that when choosing a partner in the alliance the companies themselves must take into account the concept of management that partners have developed or have been developing before entering into an alliance. The problem occurs when the role of strategic alliance controller is introduced to support the strategic alliances management, and there is no previous compatibility of partner companies in developing value-oriented management, which inevitably implies concept of controlling. In that case, the effectiveness of implemented controlling functions cannot be adequately evaluated, nor can the established controlling function adequately create value of companies in the alliance, nor can the success of strategic alliances management be measured. 
Plazibat, I.; Peronja, I. \& Veza, I.: Connection Between Strategic Alliance Value an...

\section{The role of managers and strategic alliance controllers}

Strategic alliance manager is responsible for the business and functioning of the system. Alliance management capability is a starting point in achieving competitive advantage by Kale, P.,Dyer, J.H., Singh, H (2002). Quality alliance management would mean:

- establishing a common decision-making module;

- protection of substantial knowledge of all partners;

- monitoring and controlling the information flow by both, a member company and the strategic alliances management;

- pre-established strategies for conflict resolution;

- risk management;

- managing cultural differences by Mockler, R. J (1999).

A controller should be created as an assistant for the manager so that the manager of the strategic alliance could establish a better management system and so that the manager could make decisions that have a foothold in making profit for the alliance. Strategic alliance controller is a person closely focused on the problem, profit, future and bottlenecks in the business organized on the principle of profit centres. In this way the controller divides the core objective to sub-objectives (forming "an objective tree" of the strategic alliance), and thus delegates responsibility to the management of the alliance members that are formed as profit centres. The strategic alliance controller monitors the realization the mission through realization of the volume of the guarantee contribution of each profit centre, and the controller establishes the responsibilities of each profit centre for the business results. Apart from the conditional goal, i.e. making profit, both, the controller and the manager are oriented on creating long-term sustainable competitive advantage of strategic alliance. Accordingly, they both work on a system of knowledge about managing strategic alliance.

The ability to manage complex organizational forms such as strategic alliances is considered to be tacit knowledge that is difficult to form and difficult to copy by Anand, B. B., Khanna, T. (2000). The question is how companies learn to manage an alliance, or how they acquire management skills essential for a strategic alliance.

This issue includes two segments:

- How do individuals within strategic alliance gain knowledge?

- How does a strategic alliance gather the individual knowledge and form a collective know-how to (at the alliance level)?

The learning ability increases with every new alliance which members join. Along with the increase of uncertainty and experience, individuals accumulate more knowledge about alliances. They also begin to understand 'the learning to learn' by Dussage, P., Garrette, B., Mitchell, W. (2000).

This results in differences in alliance management skills because every alliance at its operational level differently organizes accumulation, codification and sharing of knowledge and information. Since there are alliances that have learnt to learn, still 
learn and invest into knowledge, and those that have failed to invest into learning and will not do so, the gap of knowledge and learning abilities between strategic alliances deepens over time, which affects the competitiveness of the union as a whole.

\section{Management compatibility of partners in the alliance- the process of selecting partners}

The process of selecting a partner for strategic partnership determines future outcome of the alliance, as well as future needs, norms and partners' interaction. Selecting a partner for strategic alliance is not an easy decision. It is defined by network of variables depending on the complexity of future strategic alliance. Selecting partners for the formation of a strategic alliance is marked with the desirability that partners match. Matching partner means a complementary mission of companies, resources, skills, managerial skills, and all the other elements necessary to create a strategic compatibility of partners that will equalzie bargaining power of all the partners in the alliance.

Many theorists believe that the criteria for partner selection are redefined as the environment and elements of related industry cyclically change by Overby, M. L. (2010). It should be noted that partners' selection means not only the selection of the company but also of its employees by Medcof, John W. (1997).

Essential strategic intentions of partners rarely encourage cooperation of partners at the individual level. Partners typically lack mutual understanding, familiarity, trust, and the lack of these factors may result in conflicting relationships by Doz, Y. L., Hamel, G. (1998).

This gap between social skills in accepting partners may be reduced if the partner is thoughtfully selected based on strategic intent in the first step of this phase. Identification and selection of a compatible partner is a complex process that involves not only the strategic and organizational matching of partners, but also an equally important aspect of human relationships of all staff involved in the alliance (i.e. social capital). This means that in this step partners not only seek identical or similar strategic intent of companies, but also seek operational and social match of potential partners. Afterwards, there comes a period of partners adaptation. If the period of adaptation proves that the partner or the partners have been well selected, then this period will not be "traumatic" for the company nor for any of its employees.

Partners' adaptation should after some time reduce the initially noticed distrust and opportunistic desires. Partners must, at an early stage, develop mutual trust and the ability of cooperation. They must overcome the initial gaps or return to the initial steps and reconsider earlier assumptions and expectations. All the strategic alliances do not evolve or move forward at this stage. Some initial failures in the relationship such as weak mutual potential or insurmountable strategic conflicts between partners, become a stumbling block for further cooperation.

The key to subsequent long-lasting strategic alliance are learning and the ability to adapt to changes. Successful strategic alliances go through cycles of learning, revaluation and adjustment to all the troubles over time. Through the new 
adjustments and changes, the alliance strengthens its size and purpose, allowing the creation of greater and greater values.

The greatest threat to the adaptation are the tension and instabilities created at the beginning of the relationship when the partners did not realize asymmetry in their strategic intentions. Partners may have symmetrical strategic intentions even in the beginning, but as time goes by, and the alliance strengthens, they do not notice the appearance of asymmetric relations, i.e. the disappearance of identical strategic intention by Koza, M., Lewin, A. (2000).

\section{Empirical research about dependency of relationship between management and strategic alliance controller on control compatibility of member companies}

Research on the impact of controlling on the effectiveness of entities in strategic alliances in the retail trade in Croatia was conducted from November 2010 until October 2011. A sample of this research is defined by the number of strategic alliances in the retail trade in the period of conducting research, by the number of member companies in a particular alliance and by the organizational structure of the individual members. Alliance members were asked through an on-line questionnaire, which guarantees anonymity of respondents and responses. The analysis of demographic characteristics of respondents was conducted based on the collected data. Frequency tables are used to describe the sample with respect to the observed characteristics of respondents. Modality features with maximum frequency are interpreted as the most common value that appears. As it can be seen in Table 1, all respondents (97.6\%), but one come from the member companies of some strategic alliance in the retail trade. Based on the obtained results, it can be assumed that only one person answered the web questionnaire sent to the management of companies of the former triad Billa-Plodine-Mercator. Further on in the paper, it will be visible that the assumption was confirmed by the frequency of responses to question shown in table 2.

\begin{tabular}{|c|c|c|}
\hline Offered responses & Response frequency & Response structure in \% \\
\hline Yes & 40 & 97,6 \\
\hline No & 1 & 2,4 \\
\hline Total & 41 & 100,0 \\
\hline
\end{tabular}

Tab. 1. Membership in strategic alliance

\begin{tabular}{|c|c|c|}
\hline Offered responses & Response frequency & Response structure in \% \\
\hline Konzum-HOK & 7 & 17,1 \\
\hline Billa-Mercator-Plodine & 1 & 2,4 \\
\hline NTL & 20 & 48,8 \\
\hline Ultra gros & 10 & 24,4 \\
\hline Some other alliance & 3 & 7,3 \\
\hline Total & 41 & 100,0 \\
\hline
\end{tabular}

Tab. 2. Belonging to a particular strategic alliance in retail trade in The Republic of Croatia 
Table 2 shows the frequency of responses that specificity results in Table 1, and the respondents were asked to write which strategic alliance their company belongs to.

Respondents were asked to answer the question in Table 3, i.e. to assess the strategic alliance their company belongs to. As it might have been expected, the majority belongs to (85.4\%) horizontal strategic alliances. Presumably, they are socalled buying groups' alliances. $2.4 \%$ belong to the diagonal ones and $12.2 \%$ to the verticals.

\begin{tabular}{|c|c|c|}
\hline Offered responses & Response frequency & Response structure in \% \\
\hline Horizontal alliance & 35 & 85,4 \\
\hline Vertical alliance & 5 & 12,2 \\
\hline diagonal alliance & 1 & 2,4 \\
\hline Total & 41 & 100,0 \\
\hline
\end{tabular}

Tab. 3. Type of alliance

The hypothesis of the collected empirical data has been tested to determine the dependence relationship between management and strategic alliance controller on the control compatibility of the alliance member companies. Firstly it has been tested whether the human resources and operational compatibility of member companies affect cooperation between the controller and the managers assuming that the controller supports management / manager of the strategic alliance.

\begin{tabular}{|c|c|c|c|}
\hline & & \multicolumn{2}{|c|}{$\begin{array}{c}\text { Relationship controller manager (or } \\
\text { management) of the strategic alliance is also } \\
\text { based on the compatibility of strategic alliance } \\
\text { members }\end{array}$} \\
\hline & & Arithmetic mean & Median \\
\hline \multirow{3}{*}{$\begin{array}{l}\text { Assess whether all members of the } \\
\text { strategic alliance which your } \\
\text { company belongs to are compatible } \\
\text { in terms of human resources and } \\
\text { their operations? }\end{array}$} & Yes & 3,90 & 4,00 \\
\hline & No & 3,73 & 4,00 \\
\hline & $\begin{array}{l}\text { I do not } \\
\text { know }\end{array}$ & 3,89 & 4,00 \\
\hline
\end{tabular}

Tab. 4. Descriptive statistics of human resources and operational compatibility of members and relationship between managers and strategic alliance controller

In Table 4 it is evident that if the members are compatible in terms of human resources and their operations, the arithmetic mean of the cooperation is higher $(3,90)$ than when the members are not compatible $(3,73)$ in the above mentioned terms. But, their median remains the same.

However, to determine the significance of this difference, it was necessary to test differences between the two means on independent samples. In other words, it was necessary to do the F-test assuming that the variance of basic sets is equal. The F-test is based on an analysis of variance with one variable factor (called One-way ANOVA) by Rozga, A. (2009). Therefore, two ANOVA tables were made. The first (Table 5) giving three options: "yes", "no" and "do not know" and the second (Table 
8) with only two options "yes" and "no". In the first table (Table 5), the F-test shows whether the three arithmetic means differ, while in the second (Table 6) the F-test shows whether the two arithmetic means differ. Although, the t-test is usually used to test the differences between the means of two basic sets, but the F-test was used because of the simplicity of calculation in F-test. And in testing the differences of the two means the F-test and the t-test are equivalent because in that case $F=t^{2}$

\begin{tabular}{|c|c|c|c|c|c|}
\hline \multicolumn{7}{|c|}{ A N O V A } \\
\hline & $\begin{array}{c}\text { Sum of } \\
\text { Squares }\end{array}$ & $\begin{array}{c}\text { Degrees of } \\
\text { freedom }\end{array}$ & $\begin{array}{c}\text { Mean square } \\
\text { deviation }\end{array}$ & F-ratio & p-value \\
\hline Between groups & 0,242 & 2 & 0,121 & 0,309 & 0,736 \\
\hline Within groups & 14,880 & 38 & 0,392 & & \\
\hline Total & 15,122 & 40 & & & \\
\hline
\end{tabular}

Tab. 5. Variance analysis of controller and manager relationship and human resources and operational compatibility of strategic alliances members (3-response option)

F-ratio is an empirical test value distributed according to F-distribution, in this case with two degrees of freedom in the numerator and 38 degrees of freedom in the denominator, while the p-value is the empirical level of significance, which is compared with the theoretical significance level (usually $1 \%, 5 \%$ or $10 \%$ ).In the first case, the empirical value of the F-test is 0.309 and the corresponding p-value is 0.736 . Since the empirical significance level is higher than $5 \%$, we can accept null hypothesis, or it has been proved that there is no statistically significant difference in mean values. Thus, it can be accepted that the operational and human resources compatibility of the alliance members does not affect the cooperation between the controller and manager of the alliance.

\begin{tabular}{|c|c|c|c|c|c|}
\hline \multicolumn{7}{|c|}{ A N O V A } \\
\hline & $\begin{array}{c}\text { Sum of } \\
\text { Squares }\end{array}$ & $\begin{array}{c}\text { Degrees of } \\
\text { freedom }\end{array}$ & $\begin{array}{c}\text { Mean square } \\
\text { deviation }\end{array}$ & F-ratio & p-value \\
\hline Between groups & 0,227 & 1 & 0,227 & 0,683 & 0,415 \\
\hline Within groups & 9,991 & 30 & 0,333 & & \\
\hline Total & 10,219 & 31 & & & \\
\hline
\end{tabular}

Tab. 6. Variance analysis of controller and manager relationship and human resources and operational compatibility of strategic alliances members (2-response option)

In the second case, the empirical value of the F-test is 0.683 and the corresponding pvalue is 0.415 . Although the p-value of has been reduced, it is still significantly higher than 5\%, and the null hypothesis can again be accepted. Thus, it has been proved that there is no statistically significant difference between the observed mean values, and in this case it is accepted that operational and human resources compatibility of the alliance members does not affect the cooperation between the controller and manager of the alliance.

Further in the paper we will analyse indicators relating the selection of alliance partners as well as essential operational and human resource compatibility of alliance members. 


\begin{tabular}{|l|c|c|}
\hline & & $\begin{array}{c}\text { Assess whether you had planned to } \\
\text { find partner compatible to you in } \\
\text { control function prior joining the } \\
\text { alliance? }\end{array}$ \\
\hline & & Arithmetic Mean \\
\hline $\begin{array}{l}\text { Assess whether all members of the strategic } \\
\text { alliance which your company belongs to are } \\
\text { compatible in terms of human resources and } \\
\text { their operations? }\end{array}$ & Yes & 3,43 \\
\cline { 2 - 3 } & no & \\
\hline
\end{tabular}

Tab.7. Arithmetic mean of "selecting" partners and human resources and operational compatibility of the alliance members

Significance of difference (table 7) between the two means (table 8) of selecting partners and compatibility in human resources and operations has been tested

\begin{tabular}{|c|c|c|c|c|c|}
\hline \multicolumn{7}{|c|}{ A N O V A } \\
\hline & $\begin{array}{c}\text { Sum of } \\
\text { Squares }\end{array}$ & $\begin{array}{c}\text { Degrees of } \\
\text { freedom }\end{array}$ & $\begin{array}{c}\text { Mean square } \\
\text { deviation }\end{array}$ & F-ratio & p-value \\
\hline Between group & 1,667 & 1 & 1,667 &, 481 &, 493 \\
\hline Within group & 104,052 & 30 & 3,468 & & \\
\hline Total & 105,719 & 31 & & & \\
\hline
\end{tabular}

Tab. 8. Variance analysis of "selecting" partners and human resources and operational compatibility of strategic alliances members

It is evident that the p-value of $49.3 \%$ shows that even in this case there is no statistically significant difference in mean values, i.e., there is no basis to reject the null hypothesis. Therefore, we can say that human resources and operational compatibility is not a criterion for selecting a compatible partner for an alliance.

Furthermore, the nonparametric chi-square test was used to test the relationship between the "partner selection" and "alliance members compatibility".

\begin{tabular}{|c|c|c|c|}
\hline & $\begin{array}{c}\text { The value } \\
\text { of the test }\end{array}$ & $\begin{array}{c}\text { The } \\
\text { degrees of } \\
\text { freedom }\end{array}$ & p-value \\
\hline Pearson chi-square & 7,668 & 5 & 0,175 \\
\hline credibility ratio & 7,997 & 5 & 0,156 \\
\hline linear association measure & 0,489 & 1 & 0,484 \\
\hline The sample size & 32 & & \\
\hline
\end{tabular}

Tab. 9. Chi-square test of "partner selection" and human resources and operational compatibility of member companies

Credibility ratio and linear association measure are test values that are additionally calculated by the chi-square test and are associated with it (table 11). Linear association measure is a square root of ratio of Pearson chi-square and the sample size: 


$$
\sqrt{\frac{\chi^{2}}{n}}=\sqrt{\frac{7,668}{32}}=0,484
$$

And it is interpreted as the linear correlation coefficient, the value of which cannot be negative, meaning that for the nominal variables only the intensity of connection can be determined and not its direction. That is why this ratio is called linear association measure Value of 0.484 indicates medium strong correlation between the two observed variables. However it is not statistically significant because the p-value is higher than $10 \%$. In this case, the sample size is lower than 41 because all the respondents did not answer the questions.

The chi-squared value of 7.668 (Pearson chi-square), along with the p-value of $17.5 \%$ also shows that the two mentioned characteristics are not mutually dependent, in other words the null hypothesis is accepted. Again, the claim that human resources and operational compatibility of member companies is a criterion for selecting a compatible partner for an alliance has been rejected

\begin{tabular}{|c|c|c|c|c|c|c|c|c|}
\hline & & \multicolumn{7}{|c|}{$\begin{array}{l}\text { Assess whether you had planned to find partner } \\
\text { compatible to you in control function prior joining } \\
\text { the alliance? }\end{array}$} \\
\hline & & 1 & 2 & 3 & 4 & 5 & 6 & Total \\
\hline \multirow{3}{*}{$\begin{array}{l}\text { Assess whether all members } \\
\text { of the strategic alliance which } \\
\text { your company belongs to are } \\
\text { compatible in terms of human } \\
\text { resources and their operations? }\end{array}$} & Yes & 4 & 5 & 1 & 5 & 1 & 5 & 21 \\
\hline & No & 1 & 1 & 4 & 1 & 0 & 4 & 11 \\
\hline & Total & 5 & 6 & 5 & 6 & 1 & 9 & 32 \\
\hline
\end{tabular}

Tab. 10. Distribution of frequency responses for "partner selection" and human resources and operational compatibility of member companies

However, if the frequency responses to these two questions are compared (Table 10), it can be concluded that an equal number of respondents (5) answered they "slightly" planned to find a compatible partner and 5 of them "really" planned to find a compatible partner. Frequencies have confirmed that members of the alliance which they belong to are compatible in both, human resources and operations. It can also be concluded that in some alliances partners compatibility is coincidental, not intentional, i.e. conditioned if it is considered that four respondents denied the search for a compatible partner, while simultaneously confirming the compatibility of their alliance members. It is evident that out of 9 respondents who "do not know" if the compatibility was a requirement in the search for a new member of their alliance, 5 gave an affirmative answer that their alliance members are compatible (confirmation of random compatibility), while 4 do not consider the members compatible.

Following obtained results, we wanted to show the influence of the support management on cooperation between controllers and managers. In table 11 it is evident that the average grade of controller as support to alliances manager is the 
highest if the controller is present in defining the objectives of the business alliance (4.12) and the lowest (3.57) if not present.

\begin{tabular}{|c|c|c|}
\hline & & $\begin{array}{l}\text { A controller is a support to manager } \\
\text { (management) of strategic alliance }\end{array}$ \\
\hline & & Arithmetic mean \\
\hline \multirow{4}{*}{$\begin{array}{l}\text { Is a controller as a partner } \\
\text { and support to manager } \\
\text { (or management) present } \\
\text { in your strategic alliance } \\
\text { in defining business } \\
\text { objectives? }\end{array}$} & Yes & 4,12 \\
\hline & No & 3,57 \\
\hline & I am not aware & 4,00 \\
\hline & I don't know & 4,33 \\
\hline
\end{tabular}

Tab. 11. Arithmetic mean - Does support management influence cooperation between controllers and managers

And in this case we conducted the significance test with differences between the two means for independent samples, i.e. the F-test based on variance analysis with one variable factor (called Oneway ANOVA). There are also two ANOVA tables. The first with four options response, and the second which leaves out options "do not know" and "I am not aware", but includes responses "yes" and "no".

\begin{tabular}{|c|c|c|c|c|c|}
\hline \multicolumn{7}{|c|}{ A N O V A } \\
\hline & $\begin{array}{c}\text { Sum of } \\
\text { Squares }\end{array}$ & $\begin{array}{c}\text { Degrees } \\
\text { of } \\
\text { freedom }\end{array}$ & $\begin{array}{c}\text { Mean } \\
\text { square } \\
\text { deviatio } \\
\mathrm{n}\end{array}$ & F-ratio & p-value \\
\hline Between group & 2,163 & 3 & 0,721 & 1,801 & 0,164 \\
\hline Within group & 14,812 & 30 & 0,400 & & \\
\hline Total & 16,976 & 40 & & & \\
\hline
\end{tabular}

Tab. 12. Variance analysis - Does support to management influence cooperation between controllers and managers (4-answer option)

The differences between the four arithmetic means (Table 12) shows that there is no statistically significant difference because the empirical level of significance is higher than $5 \%(\mathrm{p}$-value $=16.4 \%)$.

\begin{tabular}{|c|c|c|c|c|c|}
\hline \multicolumn{2}{|c|}{ A N O V A } & p-value \\
\hline & $\begin{array}{c}\text { Sum of } \\
\text { Squares }\end{array}$ & $\begin{array}{c}\text { Degrees } \\
\text { of } \\
\text { freedom }\end{array}$ & $\begin{array}{c}\text { Mean } \\
\text { square } \\
\text { deviatio } \\
\mathrm{n}\end{array}$ & F-ratio & \\
\hline Between group & 1,479 & 1 & 1,479 & 3,433 & 0,077 \\
\hline Within group & 9,479 & 22 & 0,431 & & \\
\hline Total & 10,958 & 23 & & & \\
\hline
\end{tabular}

Tab. 13. Variance analysis - Does support to management influence cooperation between controllers and managers (2-answer option) 
If the categories "I do not know" and "I am not aware" are left out (Table 13), we get the p-value higher than $5 \%$, but lower than $10 \%$ (i.e. it is $7.7 \%$ ). This means that theoretically at significance level of $10 \%$, the research hypothesis may be accepted and the null hypothesis rejected confirming that there is a statistically significant difference between the observed mean values, what is acceptable considering the sample size. This, it can be accepted that the presence of controllers as support to management affects cooperation betweeen controllers and managers in an alliance. Considering performed analysis it can be concluded that relationship between management and strategic alliances controller does not depend on the compatibility management of member companies.

When compared:

- the influence of human resources and operational compatibility of member companies on cooperation between controller and the alliance managementrejected;

- searching a partner compatible in human resources and operations with members - also rejected;

- the influence of support to management (controller) on cooperation between the controller and the manager is accepted.

The obtained results did not prove the partner compatibility to be primary, although it was primarily a required condition. It is assumed that the partner compatibility arises from a bad or poor definition of potential, new partner when forming alliances of companies in retail trade in Croatia (this is confirmed by frequency response to "partner selection" and Human Resources and operational compatibility of member companies in table 12).

In other words, it is considered that enough importance is still not given to defining elements in partner selection. In doing so, human resources, operational and management compatibility should be one of the key requirements, which is the foundation for building a so-called strategic partner congruence by Medcof, John W. (1997). Lack of management, human resources and operational compatibility of member companies may jeopardize the growth and future of the alliances. Mentioned compatibility is also the mainstay to development of commitment to alliance goals and it can jeopardize the achievement of the set objectives of the alliance and weaken the alliance loyalty.

Proof of this is the increasing migration of member companies from one alliance to another, the dissolution of the alliance before the end of the contract and before the fulfilling the set objectives. However, it should be pointed out that in case of strategic alliances called buying groups (which are still the most common form of alliance of companies retail trade, as it can be seen in Table 6) then management, operational and human resources compatibility are not a necessary condition, as the results of the survey showed. In such alliances it is only essential to "collect" a critical mass of member companies to get better supply conditions. But if the goal is more complex, then mentioned compatibility must be conditio sine qua non. 


\section{Conclusion}

Consolidation of retailers in strategic alliances creates new market power and knowledge that itself can be the sole subject of trade. There are several definitions of strategic alliances. However, they all commonly describe them as partnerships of companies in which they maintain their independence while achieving the defined common goal along with the essential synergistic effect. Given its prevalence and attractiveness, a number of classifications of strategic alliances have developed. When analysing them, the most commonly used classification is the one with regard to a number of companies in the alliance, as well as ways of connecting members. Each type of strategic alliance has its advantages and disadvantages and is more or less suitable, or characteristic of connecting companies in a particular industry. There are several motives that encourage companies to enter or form strategic alliances. The motive itself is always related to the objective that is to be achieved, and which the companies did not knew how or could not achieve independently. Apart from achieving the objective, the purpose of the strategic alliance is increasing the competitive advantage, and thus the value of the member companies.

The conducted research pointed out that human resources and operational compatibility of member companies does not affect the alliance cooperation between controller and managers of the alliance. It also indicated that the relationship between management and strategic alliance controller does not depend on the compatibility management of member companies. The reason for this probably lies in the fact that most companies, according to respondents' answers, are members of horizontal alliances mainly founded to achieve the volume of procurement and for which the compatibility was not condition sine qua non. Therefore, it is confirmed that the companies in retail usually enter buying groups' alliances. Thus request for a management compatible partner is not accepted. However, it was confirmed and proved that the presence of controller affects cooperation as a support to strategic alliances manager. Although compatibility of member companies has not been proved, it can be argued it is not the condition in strategic alliances in retail trade if they are of buying groups type which is based on the number, i.e. volume.

\section{Acknowledgements}

This work has been fully supported by Croatian Science Foundation under the project 1353 Innovative Smart Enterprise (INSENT).

\section{References}

Alfirevic, A.,M., Peronja, I., Plazibat, I., Business Excellence in Croatian Hotel Industry: Results of Empirical Research, DAAAM International Scientific Book, ISBN 978-3-901509-94-0, ISSN 1726-9687, Vienna, Austria, 2013., 657

Anand, B. B., Khanna, T.: Do firms learn to create value? The case of alliances, Strategic Management Journal, Vol. 21., No. 3., 2000., pgs. 295.-315 
Ding, J.F., Liang, G.S.: Using fuzzy MCDM to select partners of strategic alliances for liner shipping, Information Sciences, Vol. 173., No. 1.-3., 2005, pgs 197.-225

Doz, Y. L., Hamel, G.: Alliance Advantage. The Art of Creating Value through Partnering, Harvard Business School Press, Boston, 1998, pgs 146

Dussage, P., Garrette, B., Mitchell, W.: Learning from competing partners: outcomes nad durations of scale and link alliances in Europe, North America and Asia, Strategic Management Journal,Vol. 21., 2000, pgs 99.-126

Fenollera, M., Lorenzo, J., Risk Management: An Adaptation for a SME , DAAAM International Scientific Book, DAAAM International, ISBN 978-3-901509-84-1, ISSN 1726-9687,Vienna, Austria, 2011., pgs. 477.-494

Gulati, R.: Network location and learning: The influence of network resources anf firm capabilities on alliance formation, Strategic Management Journal, Vol. 20., Issue 5., 1999, pgs. 397.-420

Kale, P.,Dyer, J.H., Singh, H.: Alliance capability, stock market response, and longterm alliance success: The role of alliance function, Strategic Management Journal, Vol. 23., 2002, pg. 747.-767

Koza, M., Lewin, A.: Managing partnerships and strategic alliances: raising the odds of succes, European Management Journal, Vol. 18., Issue 2., 2000, pgs 146-151

Kremljak, Z., Risk Management Methods, Chapter 10 in DAAAM International Scientific Book, DAAAM International, ISBN 978-3-901509-84-1, ISSN 1726-9687, Vienna, Austria, 2011.,pgs.121

Lindner, R.: Controlling strategischer Allianzen im FuE - Bereich, Diplomarbeit, Universität Hohenheim, Hohenheim, 2001

Luković, T., Lebefromm, U.: Controlling, concept aned the cases, First Book, University in Dubrovnik, 2009., pg 13

Medcof, John W.: Why Too Many Alliances End in Divorce, Long Range Planning, Vol. 30., No. 5., 1997,pgs 718.-732

Mockler, R. J.: Multinational Strategic Alliances, John Wiley \& Sons, 1999, pg. 136

Mockler, R. J.: Multinational Strategic Alliances, John Wiley \& Sons, 1999, pgs 62 Osmanagić Bedenik, N.: Controlling: Alphabet Business Success, 2nd edition,

Overby, M. L.: Partner selection criteria in strategic alliances: When to ally with weak partners?, available

http://www2.druid.dk/conferences/viewpaper.php?id=2529\&cf=17 (31st August 2010)

Palcic, I., Buchmeister, B., Project Success in Slovenian Companies, Chapter 05 ., DAAAM International Scientific Book,ISBN 978-3-901509-86-5, ISSN 1726-9687, Vienna, Austria, 2012., pgs.055

Prema Doz, Y. L., Hamel, G.: Alliance Advantage. The Art of Creating Value through Partnering, Harvard Business School Press, Boston, 1998, pg 94

Rozga, A.: Statistics for Ecomonists, Faculty of Economics Split, Split, 2009., pgs. 167.-169

Schickel, H.: Controlling internationaler strategischer Allianzen, Technische Universität Darmstadt, Darmstad, 1999. pgs. 123.-128

School books, Zagreb, 2004. pg.64

Zaboj, M.: Strategic Alliances as a Competitive Instrument of SME`s, available at: http://www.icabr.com/ fullpapers/Z\%E1boj\%20Marek.pdf (December 2010) 